\title{
Antibiotic-Related Adverse Drug Reactions at a Tertiary Care Hospital in South Korea
}

\author{
In Young Jung, ${ }^{1,2}$ Jung Ju Kim, ${ }^{1,2}$ Se Ju Lee,, Jinnam Kim, ${ }^{1,2}$ Hye Seong, \\ Wooyong Jeong, ${ }^{1,2}$ Heun Choi, ${ }^{1,2}$ Su Jin Jeong, ${ }^{1,2}$ Nam Su Ku, ${ }^{1,2}$ Sang Hoon Han, ${ }^{1,2}$ \\ Jun Yong Choi, ${ }^{1,2}$ Young Goo Song, ${ }^{1,2}$ Jung Won Park, ${ }^{1,3}$ and June Myung Kim ${ }^{1,2}$ \\ ${ }^{1}$ Department of Internal Medicine, Yonsei University College of Medicine, Seoul, Republic of Korea \\ ${ }^{2}$ AIDS Research Institute, Yonsei University College of Medicine, Seoul, Republic of Korea \\ ${ }^{3}$ Institute of Allergy, Yonsei University College of Medicine, Seoul, Republic of Korea \\ Correspondence should be addressed to Nam Su Ku; smileboy9@yuhs.ac and Jung Won Park; parkjw@yuhs.ac
}

Received 16 October 2017; Accepted 19 November 2017; Published 31 December 2017

Academic Editor: Ronald E. Baynes

Copyright (C) 2017 In Young Jung et al. This is an open access article distributed under the Creative Commons Attribution License, which permits unrestricted use, distribution, and reproduction in any medium, provided the original work is properly cited.

Background. Adverse drug reactions (ADRs) are any unwanted/uncomfortable effects from medication resulting in physical, mental, and functional injuries. Antibiotics account for up to $40.9 \%$ of ADRs and are associated with several serious outcomes. However, few reports on ADRs have evaluated only antimicrobial agents. In this study, we investigated antibiotic-related ADRs at a tertiary care hospital in South Korea. Methods. This is a retrospective cohort study that evaluated ADRs to antibiotics that were reported at a 2400 -bed tertiary care hospital in 2015. ADRs reported by physicians, pharmacists, and nurses were reviewed. Clinical information reported ADRs, type of antibiotic, causality assessment, and complications were evaluated. Results. 1,277 (62.8\%) patients were considered antibiotic-related ADRs based on the World Health Organization-Uppsala Monitoring Center criteria (certain, 2.2\%; probable, 35.7\%; and possible, 62.1\%). Totally, 44 (3.4\%) patients experienced serious ADRs. Penicillin and quinolones were the most common drugs reported to induce ADRs (both 16.0\%), followed by third-generation cephalosporins (14.9\%). The most frequently experienced side effects were skin manifestations (45.1\%) followed by gastrointestinal disorders (32.6\%). Conclusion. Penicillin and quinolones are the most common causative antibiotics for ADRs and skin manifestations were the most frequently experienced symptom.

\section{Introduction}

Adverse drug reactions (ADRs) are any unwanted/uncomfortable effects from medication resulting in physical, mental, and functional injuries [1]. ADRs experienced by hospitalized patients are associated with increased morbidity and mortality, prolonged hospitalization, and increased medical expense [2]. For this reason, several studies have suggested that ADRs are a major public health concern [3].

Disease prevalence, economic status, culture, and ethnicity all contribute to different ADR patterns $[4,5]$. The overall incidence of ADRs varies by study but ranges from $0.15 \%$ to $30 \%[1,6]$. In one study conducted at an Indian tertiary care hospital, antibiotics were responsible for $40.9 \%$ of ADRs [6]. An Australian tertiary center reported that antibiotics were related to $25 \%$ of ADRs [7]. Furthermore, previous studies have shown that $26.88 \%$ of ADRs are considered severe and that $99.47 \%$ required additional medical intervention [8].

Many observational studies have examined the incidence, pattern, and severity of ADRs, but most of these have been performed in America or Europe; reports on Asian countries are extremely rare $[7,9,10]$. Several South Korean reports have identified antibiotics as a leading cause of ADRs, but most are based on information from primary care center pharmacies, and data on ADRs related to antimicrobial agents reported from tertiary care hospitals are extremely rare.

Although a number of studies on ADRs caused by various drugs have been conducted, none have focused specifically on antibiotics. Therefore, in this study we investigated the 
frequency of antibiotic-related ADRs experienced at a tertiary health care hospital in South Korea.

\section{Materials and Methods}

2.1. Study Design. This was a retrospective cohort study based on reports from Yonsei University College of Medicine Severance Hospital, a tertiary health care hospital in Seoul, South Korea, from January 1 to December 31, 2015. Only antibiotic-related ADRs in hospitalized patients were analyzed. All antibiotics, whether administered concurrently or at a different time point, were evaluated for possibilities of ADRs and included in the analysis. Any cases of ADRs that might have been caused by concurrently administered drugs, other than antibiotics, were excluded from the analysis.

The following data were collected: date of reported ADR, age, gender, clinical manifestation, causal drug and brand name, route of administration, dates of administration and discontinuation, outcome (serious or not serious), recurrence, causality assessment, and dose-relationship. This study was approved by the Institutional Review Board (IRB) of Severance Hospital (IRB \#4-2017-0307), and the need for written informed consent from all participants was waived by the approving IRB.

2.2. Definitions. Causality was classified into three categories: certain, probable, and possible based on the WHO-Uppsala Monitoring Center criteria $[11,12]$. The severity of each ADR was classified as serious or nonserious [12]. Serious ADRs were defined as patients who experienced disability, prolonged hospitalization, life-threatening symptoms, or death [12]. Symptoms were classified according to symptom organ class (SOC) from the Medical Dictionary for Regulatory Activities (MedDRA) [13]. Defined daily dose (DDD) is the average maintenance dose per day for a drug used for its main purpose, as defined by the World Health Organization (WHO) [14]. Antimicrobial use density (AUD) describes the total antimicrobial use in DDD per 1,000 patient days of one drug class, as recommended by the WHO [14]. AUD was calculated as follows.

$$
\begin{aligned}
& \text { AUD }=(\text { total antimicrobial use }) /(D D D \times \text { patient } \\
& \text { days }) \times 1,000[15,16] .
\end{aligned}
$$

2.3. Collected Data and Reporting Sources. Severance Hospital is a 2400-bed tertiary care hospital and is one of the largest health care centers in South Korea. Severance was registered as a Regional Pharmacovigilance Center in 2006 and is using a computer-based pharmacovigilance monitoring system. ADR reporting is voluntary and can be reported by a physician, pharmacist, nurse, or patient who recognizes the ADR event. These voluntary reports are reviewed by the ADR-monitoring team, which includes a physician from the Department of Allergy and Clinical Immunology and a pharmacist. Then the clinical and demographic information of the reported ADR is stored in a pharmacovigilance system database and noted in the patient's electronic medical record (EMR). The computerized system improves medication safety by alerting medical practitioners to drug allergies and any drug-drug interactions the patient experienced.

2.4. Data Analysis. Descriptive statistic procedures were performed to analyze the ADR cases. Categorical variables are presented as numbers and percentages. All statistical tests were performed using SPSS 18.0 (Statistical Package for the Social Sciences, Chicago, IL, USA).

\section{Results}

3.1. Demographic Data, Severity, and Causality. In total, 2,032 cases of antibiotic-related ADRs were reported during the study period. Of these, $1,277(62.8 \%)$ were proven to be antibiotic-related based on the World Health Organization(WHO-) Uppsala Monitoring Center criteria. The median age was 54 years (range 35-78), and 610 (47.8\%) patients were male. Causality assessment based on WHO criteria revealed that $28(2.2 \%)$ cases were certainly caused by antibiotics, 456 (35.7\%) were probably caused by them, and 793 (62.1\%) were possibly caused by them (Figure 1). A severity assessment confirmed 44 (3.4\%) serious ADRs. Death or life-threatening events, hospital admission or prolonged hospital stay, or disability occurred in 2 cases $(4.5 \%), 38$ cases $(86.3 \%)$, and 4 cases $(9.0 \%)$, respectively.

3.2. Frequency of Antibiotic-Related ADRs and Symptoms. Penicillin and quinolones were the most frequent causes of ADRs, and both accounted for 204 cases (16\%) (Table 1). Third-generation cephalosporins accounted for 190 cases (14.9\%), second-generation cephalosporins accounted for 144 cases $(11.3 \%)$, and glycopeptides accounted for 134 cases $(10.5 \%)$.

The most common organ system affected by penicillin was the skin and subcutaneous tissue in 88 cases (43.1\%), followed by the gastrointestinal system in 61 cases $(29.9 \%)$ and immunological system in 22 cases (10.8\%). Quinolones also commonly affected the skin and subcutaneous tissue (98 cases, $48 \%$ ), followed by the gastrointestinal system (66 cases, $32.4 \%$ ) and the nervous system (16 cases 7.8\%). Thirdgeneration cephalosporins resulted in skin and subcutaneous tissue reactions in 86 cases $(45.3 \%)$, gastrointestinal reactions in 79 cases (41.6), and immunological reactions in 18 cases $(9.5 \%)$. In particular, immunologic reactions, hypersensitivity (125 cases), anaphylaxis (10 cases), StevensJohnson syndrome ( 2 cases), and angioedema (9 cases) were identified.

\subsection{Frequency of ADRs by Symptom and the Most Common} Causative Antibiotics. Skin and subcutaneous tissue disorders were the most common clinical manifestation, occurring in 576 cases $(45.1 \%)$, followed by gastrointestinal disorders, which occurred in 416 cases (32.6\%) (Figure 2).

Quinolones (98 cases, 17\%) and penicillin (88 cases, $15.3 \%$ ) were the most common causative agents for skin and subcutaneous manifestations, followed by third-generation cephalosporins in 86 cases (14.9\%) (Table 2). Gastrointestinal disorders were most often caused by third-generation 
TABLE 1: Antibiotics related ADR frequency and most common symptoms according to organ class (according to the preferred terms of MedDRA coding system).

\begin{tabular}{|c|c|c|c|}
\hline Antibiotic & Patients, $n(\%)$ & Symptom organ class & $\begin{array}{r}\text { Frequency of } \\
\text { ADRs, } n(\%)\end{array}$ \\
\hline Penicillin & $204(16)$ & $\begin{array}{c}\text { Skin and subcutaneous tissue } \\
\text { Gastrointestinal } \\
\text { Allergic } \\
\end{array}$ & $\begin{array}{l}88(43.1) \\
61(29.9) \\
22(10.8) \\
\end{array}$ \\
\hline Quinolone & $204(16)$ & $\begin{array}{c}\text { Skin and subcutaneous tissue } \\
\text { Gastrointestinal } \\
\text { Nervous system }\end{array}$ & $\begin{array}{c}98(48.0) \\
66(32.4) \\
16(7.8) \\
\end{array}$ \\
\hline $\begin{array}{l}\text { 3rd } \\
\text { cephalosporin }\end{array}$ & $190(14.9)$ & $\begin{array}{c}\text { Skin and subcutaneous tissue } \\
\text { Gastrointestinal } \\
\text { Allergic }\end{array}$ & $\begin{array}{c}86(45.3) \\
79(41.6) \\
18(9.5) \\
\end{array}$ \\
\hline $\begin{array}{l}\text { 2nd } \\
\text { cephalosporin }\end{array}$ & $144(11.3)$ & $\begin{array}{c}\text { Skin and subcutaneous tissue } \\
\text { Gastrointestinal } \\
\text { Nervous system }\end{array}$ & $\begin{array}{c}68(47.2) \\
53(36.8) \\
12(8.3) \\
\end{array}$ \\
\hline Glycopeptide & $134(10.5)$ & $\begin{array}{c}\text { Skin and subcutaneous tissue } \\
\text { Allergic } \\
\text { Blood and lymphatic system }\end{array}$ & $\begin{array}{l}83(61.9) \\
24(17.9) \\
14(10.4) \\
\end{array}$ \\
\hline Metronidazole & $61(4.8)$ & $\begin{array}{c}\text { Gastrointestinal } \\
\text { Skin and subcutaneous tissue } \\
\text { Nervous system }\end{array}$ & $\begin{array}{c}46(75.4) \\
12(19.7) \\
5(8.2) \\
\end{array}$ \\
\hline $\begin{array}{l}\text { Antituberculosis } \\
\text { medication }\end{array}$ & $61(4.8)$ & $\begin{array}{c}\text { Skin and subcutaneous tissue } \\
\text { Gastrointestinal } \\
\text { Hepatobiliary } \\
\text { Allergic }\end{array}$ & $\begin{array}{l}33(54.1) \\
7(11.5) \\
6(9.8) \\
6(9.8)\end{array}$ \\
\hline $\begin{array}{l}\text { 1st } \\
\text { cephalosporin }\end{array}$ & $53(4.2)$ & $\begin{array}{c}\text { Skin and subcutaneous tissue } \\
\text { Nervous system }\end{array}$ & $\begin{array}{c}32(60.4) \\
18(34.0) \\
6(11.3) \\
\end{array}$ \\
\hline Carbapenem & $43(3.4)$ & $\begin{array}{c}\text { Skin and subcutaneous tissue } \\
\text { Allergic } \\
\text { Gastrointestinal }\end{array}$ & $\begin{array}{c}19(44.2) \\
10(23.3) \\
8(18.6) \\
\end{array}$ \\
\hline Antifungal & $33(2.6)$ & $\begin{array}{c}\text { Allergic } \\
\text { Skin and subcutaneous tissue } \\
\text { Cardiac }\end{array}$ & $\begin{array}{c}12(36.4) \\
9(27.3) \\
6(18.2)\end{array}$ \\
\hline Antiviral & $21(1.6)$ & $\begin{array}{l}\text { Skin and subcutaneous tissue } \\
\text { Gastrointestinal } \\
\text { Blood and lymphatic system }\end{array}$ & $\begin{array}{l}8(38.1) \\
5(23.8) \\
3(14.3) \\
\end{array}$ \\
\hline Aminoglycoside & $20(1.6)$ & $\begin{array}{c}\text { Skin and subcutaneous tissue } \\
\text { Gastrointestinal } \\
\text { Renal and urinary } \\
\end{array}$ & $\begin{array}{l}12(60.0) \\
4(20.0) \\
2(10.0) \\
\end{array}$ \\
\hline Macrolide & $17(1.3)$ & $\begin{array}{c}\text { Gastrointestinal } \\
\text { Skin and subcutaneous tissue } \\
\text { Nervous system }\end{array}$ & $\begin{array}{l}7(41.2) \\
5(29.4) \\
3(17.6) \\
\end{array}$ \\
\hline Sulfonamide & $16(1.3)$ & $\begin{array}{c}\text { Gastrointestinal } \\
\text { Skin and subcutaneous tissue } \\
\text { Renal and urinary }\end{array}$ & $\begin{array}{l}9(56.2) \\
5(31.2) \\
2(12.5)\end{array}$ \\
\hline $\begin{array}{l}\text { 4th } \\
\text { cephalosporin }\end{array}$ & $16(1.3)$ & $\begin{array}{c}\text { Skin and subcutaneous tissue } \\
\text { Gastrointestinal } \\
\text { Nervous system }\end{array}$ & $\begin{array}{l}9(56.2) \\
5(31.2) \\
3(18.8)\end{array}$ \\
\hline Tetracycline & $13(1)$ & $\begin{array}{c}\text { Gastrointestinal } \\
\text { Skin and subcutaneous tissue }\end{array}$ & $\begin{array}{l}8(61.5) \\
2(15.4)\end{array}$ \\
\hline Antimalarial & $12(0.9)$ & $\begin{array}{c}\text { Skin and subcutaneous tissue } \\
\text { Gastrointestinal } \\
\text { Nervous system }\end{array}$ & $\begin{array}{l}5(41.7) \\
4(33.3) \\
4(33.3)\end{array}$ \\
\hline
\end{tabular}


TABLE 1: Continued.

\begin{tabular}{|c|c|c|c|}
\hline Antibiotic & Patients, $n(\%)$ & Symptom organ class & $\begin{array}{r}\text { Frequency of } \\
\text { ADRs, } n(\%)\end{array}$ \\
\hline Lincosamide & $9(0.7)$ & $\begin{array}{c}\text { Skin and subcutaneous tissue } \\
\text { Gastrointestinal }\end{array}$ & $\begin{array}{l}7(77.8) \\
2(22.2)\end{array}$ \\
\hline Polymyxin & $3(0.2)$ & $\begin{array}{c}\text { Renal and urinary } \\
\text { Skin and subcutaneous tissue }\end{array}$ & $\begin{array}{l}2(66.7) \\
1(33.3)\end{array}$ \\
\hline Monobactam & $1(0.1)$ & $\begin{array}{c}\text { Allergic } \\
\text { Skin and subcutaneous tissue }\end{array}$ & $\begin{array}{l}1(100) \\
1(100) \\
\end{array}$ \\
\hline Linezolid & $1(0.1)$ & Blood and lymphatic system & $1(100)$ \\
\hline
\end{tabular}

ADRs: adverse drug reactions.

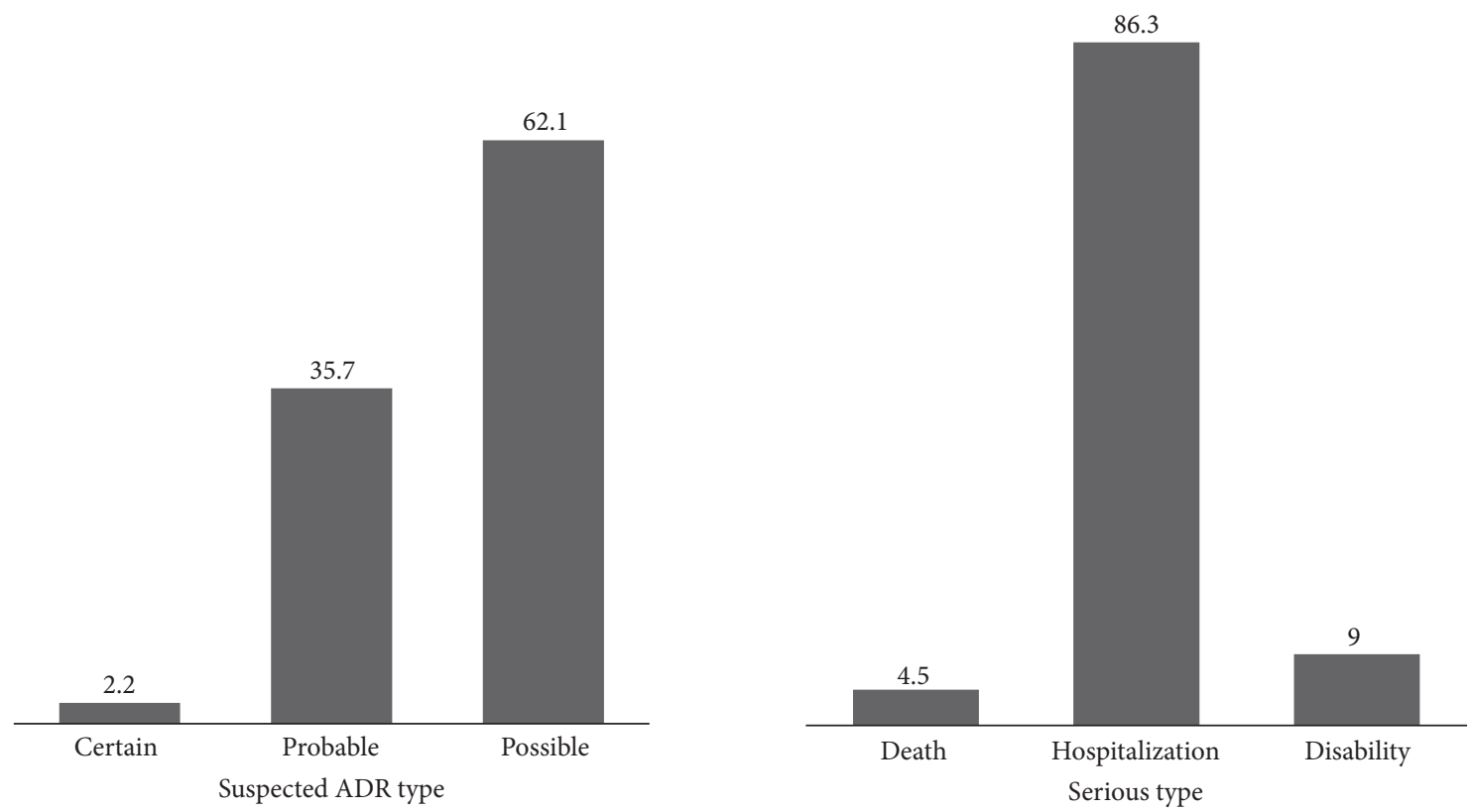

FIGURE 1: Frequency (\%) of adverse drug reaction types and serious adverse drug reactions.

cephalosporins (79 cases, $19.0 \%$ ), followed by quinolones (66 cases, $15.9 \%)$ and penicillin (61 cases, $14.7 \%)$.

3.4. Antimicrobial Use Density (AUD) to Demonstrate Each Class of Antibiotics Usage. In our study, the antibiotic uses of penicillin were 2,179.2 AUDs, followed by third-generation cephalosporin and quinolone with AUDs of 1,277.8 and 837.9, respectively (Supplementary Table 1).

\section{Discussion}

Several South Korean reports have identified antibiotics as the most common cause of ADRs [17, 18]. However, most of these reports have been based on data from private clinics and pharmacies rather than tertiary care hospitals. Here, we report the antibiotic-related ADRs experienced at a tertiary care hospital.

In this study, $3.4 \%$ of patients experienced serious ADRs. One multicenter study conducted in 2009 covering six Regional Pharmacovigilance Centers in South Korea reported that $17.7 \%$ of $\mathrm{ADRs}$ were serious [18]. A metaanalysis reported that $6.7 \%$ of ADRs were serious and that $0.32 \%$ of ADRs were fatal [19]. However, it is difficult to compare these results with our study because the previous studies included nonantibiotics such as nonsteroidal antiinflammatory drugs (NSAIDs) and radiocontrast media.

Antibiotics have been reported to be major causes of ADRs [20]. In a study that only included outpatients, sulfonamides followed by penicillin were reported to be the most common causative antibiotics [20]. Prior reports have shown that quinolones, ciprofloxacin in particular, are another common causative antibiotic [21]. This study shows that penicillin and quinolones were responsible for the majority of ADRs. These results are similar to several other South Korean reports $[18,22]$.

Geer et al. [6] reported that antituberculosis drugs accounted for $13.15 \%$ of all ADRs, and Maciel et al. [23] reported that up to $83.54 \%$ of ADRs were caused by antituberculosis drugs. In a study in Iran, gastrointestinal symptoms (22\%) and hepatotoxicity (35.7\%) were frequently 


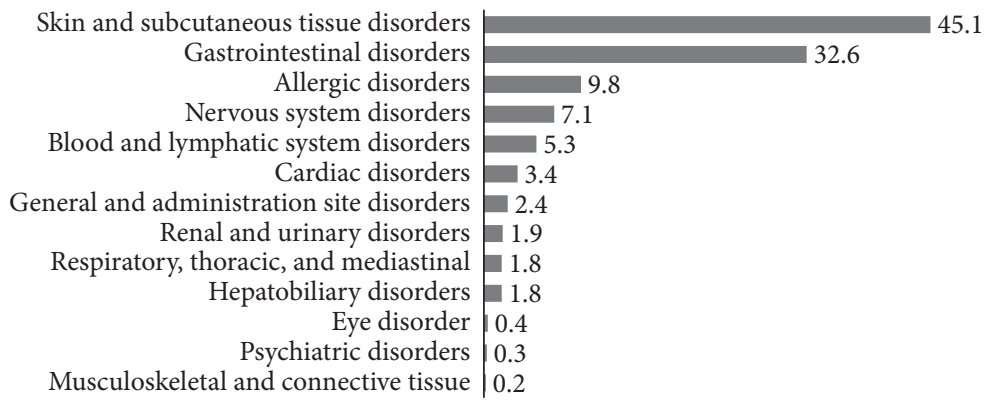

FIGURE 2: Frequency (\%) of adverse drug reaction in symptom organ class.

TABLE 2: Frequency of ADRs in symptom organ class and most common causative antibiotics (according to the preferred terms of MedDRA coding system).

\begin{tabular}{|c|c|c|c|}
\hline Symptom organ class & $\begin{array}{c}\text { Patients, } n \\
(\%)\end{array}$ & Antibiotics & $\begin{array}{l}\text { Frequency of } \\
\text { ADRs, } n(\%)\end{array}$ \\
\hline $\begin{array}{l}\text { Skin and subcutaneous } \\
\text { tissue disorders }\end{array}$ & $576(45.1)$ & $\begin{array}{c}\text { Quinolone } \\
\text { Penicillin } \\
\text { 3rd cephalosporin }\end{array}$ & $\begin{array}{l}98(17.0) \\
88(15.3) \\
86(14.9)\end{array}$ \\
\hline Gastrointestinal disorders & $416(32.6)$ & $\begin{array}{l}\text { 3rd cephalosporin } \\
\text { Quinolone } \\
\text { Penicillin }\end{array}$ & $\begin{array}{l}79(19.0) \\
66(15.9) \\
61(14.7)\end{array}$ \\
\hline Allergic disorders & $125(9.8)$ & $\begin{array}{c}\text { Glycopeptide } \\
\text { Penicillin } \\
\text { 3rd cephalosporin }\end{array}$ & $\begin{array}{l}24(19.2) \\
22(17.6) \\
18(14.4)\end{array}$ \\
\hline Nervous system disorders & $91(7.1)$ & $\begin{array}{l}\text { Quinolone } \\
\text { 3rd cephalosporin } \\
\text { 2nd cephalosporin }\end{array}$ & $\begin{array}{l}16(17.6) \\
14(15.4) \\
12(13.2) \\
\end{array}$ \\
\hline $\begin{array}{l}\text { Blood and lymphatic } \\
\text { system disorders }\end{array}$ & $68(5.3)$ & $\begin{array}{c}\text { Penicillin } \\
\text { Glycopeptide } \\
\text { 3rd cephalosporin }\end{array}$ & $\begin{array}{c}20(29.4) \\
14(20.6) \\
8(11.8)\end{array}$ \\
\hline Cardiac disorders & $43(3.4)$ & $\begin{array}{l}\text { Quinolone } \\
\text { 3rd cephalosporin } \\
\text { 2nd cephalosporin }\end{array}$ & $\begin{array}{l}8(18.6) \\
7(16.3) \\
7(16.3)\end{array}$ \\
\hline $\begin{array}{l}\text { General disorders and } \\
\text { administration site } \\
\text { conditions }\end{array}$ & $31(2.4)$ & $\begin{array}{l}\text { Quinolone } \\
\text { Antiviral agent }\end{array}$ & $\begin{array}{c}11(61.1) \\
2(11.1)\end{array}$ \\
\hline Renal and urinary disorders & $24(1.9)$ & $\begin{array}{c}\text { Glycopeptide } \\
\text { Penicillin } \\
\text { Antifungal agent } \\
\end{array}$ & $\begin{array}{l}5(20.8) \\
5(20.8) \\
3(12.5) \\
\end{array}$ \\
\hline $\begin{array}{l}\text { Respiratory, thoracic, and } \\
\text { mediastinal disorders }\end{array}$ & $23(1.8)$ & $\begin{array}{c}\text { 3rd cephalosporin } \\
\text { Antifungal agent } \\
\text { Penicillin }\end{array}$ & $\begin{array}{l}6(26.1) \\
5(21.7) \\
4(17.4)\end{array}$ \\
\hline Hepatobiliary disorders & $23(1.8)$ & $\begin{array}{c}\text { Anti-TB medication } \\
\text { Penicillin } \\
\text { Carbapenem }\end{array}$ & $\begin{array}{l}6(26.1) \\
3(13.0) \\
3(13.0)\end{array}$ \\
\hline Eye disorder & $5(0.4)$ & $\begin{array}{l}\text { Anti-TB medication } \\
\text { Penicillin }\end{array}$ & $\begin{array}{l}4(80.0) \\
1(20.0)\end{array}$ \\
\hline Psychiatric disorders & $4(0.3)$ & $\begin{array}{c}\text { 2nd cephalosporin } \\
\text { Carbapenem } \\
\text { Quinolone }\end{array}$ & $\begin{array}{l}2(50.0) \\
1(25.0) \\
1(25.0)\end{array}$ \\
\hline $\begin{array}{l}\text { Musculoskeletal and } \\
\text { connective tissue disorders }\end{array}$ & $2(0.2)$ & $\begin{array}{c}\text { Penicillin } \\
\text { Antifungal agent }\end{array}$ & $\begin{array}{l}1(50.0) \\
1(50.0)\end{array}$ \\
\hline
\end{tabular}

ADRs: adverse drug reactions; TB: tuberculosis. 
experienced ADRs caused by antituberculosis drugs [24]. In this study, antituberculosis medications made up a smaller proportion ( 61 cases $4.8 \%$ ) of ADRs; however, gastrointestinal reactions (11.5\%) and hepatotoxicity (9.8\%) were both common symptoms experienced in our study, which is similar to the results of previous studies. Isoniazid was accountable for nausea/vomiting in 2 cases, hepatobiliary disorders in 4 cases, and skin and subcutaneous tissue disorders in 8 cases, and 1 case was associated with anaphylaxis. Rifampin was accountable for nausea/vomiting, skin and subcutaneous tissue disorders, and allergic disorders in 3, 9, and 4 cases, respectively. 1 case was associated with rifampin induced Stevens-Johnson syndrome. Ethambutol ADRs were mostly associated with skin and subcutaneous tissue disorders (13 cases), and ethambutol induced optic neuritis was confirmed in 4 cases. The majority of pyrazinamide ADRs were also skin and subcutaneous tissue disorders, 5 cases.

Of all cutaneous ADRs considered in a previous study, antibiotics were the main cause (46.55\%) [25]; in another study, antibiotics accounted for $48 \%$ of delayed cutaneous ADRs, $20 \%$ of which were purportedly due to glycopeptides and sulfonamides [26]. In particular, glycopeptides and sulfonamides were implicated in 20\% of these ADRs [26]. In our study, $45.1 \%$ of skin and soft tissue ADRs were due to antimicrobial agents. Quinolones, penicillin, thirdgeneration cephalosporins, and glycopeptides were the most common causative antibiotics for skin and subcutaneousrelated ADRs. The difference in causative antibiotics may be explained by the ethnicities included in each study [5]. Further studies on the mechanisms behind causative antibiotics and reactions are needed.

Penicillin allergies are more common in females [27], as is the frequency of ADRs [28]. We also found a slight female predominance in our study $(47.8 \%$ of patients who experienced ADRs were male).

There were several limitations to our study. First, it was a single-center study and lacked reports from private clinics and other Asian countries. Further studies regarding antibiotics and ADRs are necessary to validate our results and provide more generalizable data covering all Asian countries. Second, reports of ADRs are voluntary at our hospital, so many cases could have gone unreported. Third, only data on hospitalized patients were collected; ADRs of outpatients were not included in the study. Finally, DDD is a unit of measurement and does not necessarily reflect the recommended dose or prescribed daily dose (PDD). The PDD for each class of antibiotic was not reported by the pharmacovigilance monitoring system used in this study. As there is a known discrepancy between the PDD and the daily DDD, further validation by PDDs would be necessary for accurate comparisons between antibiotics.

\section{Conclusions}

In conclusion, penicillin and quinolones were the most common antibiotic causes of ADRs. The most frequently experienced clinical feature was skin manifestations. These findings may help identify patterns and causative antibiotics of ADRs in Asian countries.

\section{Conflicts of Interest}

The authors declare they have no conflicts of interest.

\section{Authors' Contributions}

Nam Su Ku and Jung Won Park contributed equally to this article.

\section{Acknowledgments}

This research was supported by a grant from the Ministry of Food and Drug Safety for the operation of the Regional Pharmacovigilance Center in 2017.

\section{Supplementary Materials}

Supplementary Table 1. Uses of antibiotics during study period, describing the antimicrobial use density (AUD) for each class of antibiotics to demonstrate antibiotics usage during the study period. AUD was a defined daily dose (DDD) per 1,000 patient days. DDD is the average maintenance dose per day for a drug used for its main purpose, as defined by the World Health Organization (WHO). AUD was calculated as (total antimicrobial use)/(DDD $\times$ patient days) $\times 1,000$ with reference to prior studies. (Supplementary Materials)

\section{References}

[1] D. W. Bates, "Incidence of adverse drug events and potential adverse drug events. Implications for prevention. ADE Prevention Study Group," Journal of the American Medical Association, vol. 274 , no. 1, pp. 29-34.

[2] D. C. Classen, "Adverse drug events in hospitalized patients. Excess length of stay, extra costs, and attributable mortality," Journal of the American Medical Association, vol. 277, no. 4, pp. 301-306.

[3] C. Lacoste-Roussillon, "Incidence of serious adverse drug reactions in general practice: A prospective study," Clinical Pharmacology \& Therapeutics, vol. 69, no. 6, pp. 458-462, 2001.

[4] S. L. Chan, S. Jin, M. Loh, and L. R. Brunham, "Progress in understanding the genomic basis for adverse drug reactions: a comprehensive review and focus on the role of ethnicity," Pharmacogenomics, vol. 16, no. 10, pp. 1161-1178, 2015.

[5] E. Eliasson, "Ethnicity and adverse drug reactions," BMJ, vol. 332, no. 7551, pp. 1163-1164, 2006.

[6] M. Geer, P. Koul, S. Tanki, and M. Shah, "Frequency, types, severity, preventability and costs of Adverse Drug Reactions at a tertiary care hospital," Journal of Pharmacological and Toxicological Methods, vol. 81, pp. 323-334, 2016.

[7] J. A. Trubiano, K. A. Cairns, J. A. Evans et al., "The prevalence and impact of antimicrobial allergies and adverse drug reactions at an Australian tertiary centre," BMC Infectious Diseases, vol. 15, no. 1, 2015 .

[8] S. Sharma, V. Khajuria, V. Mahajan, Z. Gillani, . Richa, and V. Tandon, "Adverse drug reactions profile of antimicrobials: A 3year experience, from a tertiary care teaching hospital of India," Indian Journal of Medical Microbiology, vol. 33, no. 3, p. 393, 2015. 
[9] A. K. Jha, G. J. Kuperman, E. Rittenberg, J. M. Teich, and D. W. Bates, "Identifying hospital admissions due to adverse drug events using a computer-based monitor," Pharmacoepidemiology and Drug Safety, vol. 10, no. 2, pp. 113-119, 2001.

[10] R. S. Evans, J. F. Lloyd, G. J. Stoddard, J. R. Nebeker, and M. H. Samore, "Risk Factors for Adverse Drug Events: A 10-Year Analysis," Annals of Pharmacotherapy, vol. 39, no. 7-8, pp. 11611168, 2005.

[11] M. Helling and J. Venulet, "Drug recording and classification by the WHO research centre for international monitoring of adverse reactions to drugs," Methods of Information in Medicine, vol. 13, no. 3, pp. 169-178, 1974.

[12] I. R. Edwards and J. K. Aronson, "Adverse drug reactions: definitions, diagnosis, and management," The Lancet, vol. 356, no. 9237, pp. 1255-1259, 2000.

[13] G. Ozcan, E. Aykac, Y. Kasap, N. T. Nemutlu, E. Sen, and N. D. Aydinkarahaliloglu, "Adverse Drug Reaction Reporting Pattern in Turkey: Analysis of the National Database in the Context of the First Pharmacovigilance Legislation," Drugs - Real World Outcomes, vol. 3, no. 1, pp. 33-43, 2016.

[14] W. H. Organization, WHO Collaborating Centre for Drug Statistics Methodology. Guidelines for ATC classification and DDD assignment, Oslo, Norway, 2017.

[15] J. Yoshida, Y. Harada, T. Kikuchi, I. Asano, T. Ueno, and N. Matsubara, "Does antimicrobial use density at the ward level influence monthly central line-associated bloodstream infection rates?" Infection and Drug Resistance, p. 331.

[16] S. Murata, T. Mushino, H. Hosoi et al., "Real-time monitoring of antimicrobial use density to reduce antimicrobial resistance through the promotion of antimicrobial heterogeneity in a haematology/oncology unit," Journal of Antimicrobial Chemotherapy, vol. 70, no. 9, pp. 2661-2664, 2015.

[17] H. Kwon, S. Lee, S. Kim et al., "Spontaneously Reported Hepatic Adverse Drug Events in Korea: Multicenter Study," Journal of Korean Medical Science, vol. 27, no. 3, p. 268, 2012.

[18] Y. S. Shin, Y. Lee, Y. H. Choi et al., "Spontaneous reporting of adverse drug events by Korean regional pharmacovigilance centers," Pharmacoepidemiology and Drug Safety, vol. 18, no. 10, pp. 910-915, 2009.

[19] J. Lazarou, B. H. Pomeranz, and P. N. Corey, "Incidence of adverse drug reactions in hospitalized patients: a meta- analysis of prospective studies," The Journal of the American Medical Association, vol. 279, no. 15, pp. 1200-1205, 1998.

[20] E. Macy and T. Poon K-Y, "Self-reported Antibiotic Allergy Incidence and Prevalence: Age and Sex Effects," American Journal of Medicine, vol. 122, no. 8, pp. 778.e1-778.e7, 2009.

[21] J. L. Basko-Plluska, J. P. Thyssen, and P. C. Schalock, "Cutaneous and systemic hypersensitivity reactions to metallic implants," Dermatitis, vol. 22, no. 2, pp. 65-79, 2011.

[22] J. Lee, K. H. Park, H. J. Moon, Y. W. Lee, J. Park, and C. Hong, "Spontaneous Reporting of Adverse Drug Reactions through Electronic Submission from Regional Society Healthcare Professionals in Korea," Yonsei Medical Journal, vol. 53, no. 5, p. $1022,2012$.

[23] E. L. Maciel, L. M. Guidoni, and J. L. Favero, "Adverse effects of the new tuberculosis treatment regimen recommended by the Brazilian Ministry of Health," Jornal Brasileiro de Pneumologia, vol. 36, pp. 232-238, 2010.

[24] A. Farazi, M. Sofian, M. Jabbariasl, and S. Keshavarz, "Adverse Reactions to Antituberculosis Drugs in Iranian Tuberculosis Patients," Tuberculosis Research and Treatment, vol. 2014, pp. 16, 2014.
[25] K. Doshi, R. Yegnanarayan, and N. Gokhale, "A Retrospective Study of Drug Induced Cutaneous Adverse Reactions (CADR) in Patients Attending Tertiary Care Hospital," Current Drug Safety, vol. 11, no. 999, pp. 1-1, 2016.

[26] J. A. Trubiano, A. K. Aung, M. Nguyen et al., "A Comparative Analysis Between Antibiotic- and Nonantibiotic-Associated Delayed Cutaneous Adverse Drug Reactions," The Journal of Allergy and Clinical Immunology: In Practice, vol. 4, no. 6, pp. 1187-1193, 2016.

[27] M. A. Park, D. Matesic, P. J. Markus, and J. T. Li, "Female sex as a risk factor for penicillin allergy," Annals of Allergy, Asthma \& Immunology, vol. 99, no. 1, pp. 54-58, 2007.

[28] C. Domecq, C. A. Naranjo, I. Ruiz, and U. Busto, "Sexrelated variations in the frequency and characteristics of adverse drug reactions," International Journal of Clinical Pharmacology, Therapy, and Toxicology, vol. 18, no. 8, pp. 362-366, 1980. 


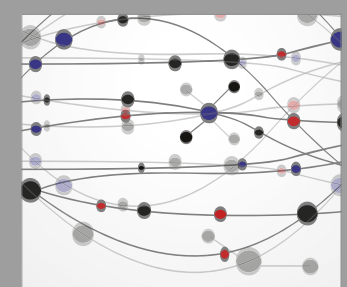

The Scientific World Journal
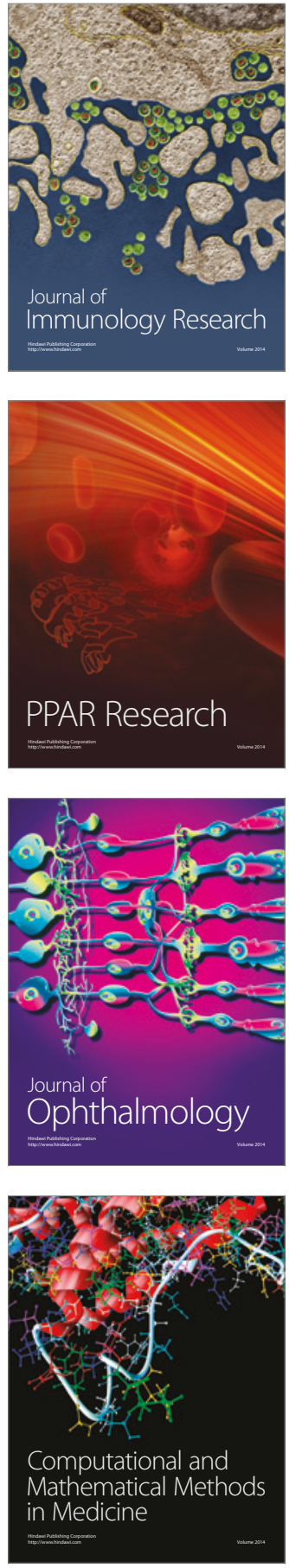

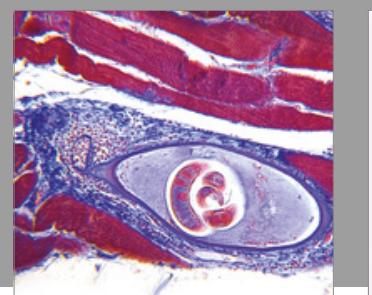

Gastroenterology Research and Practice
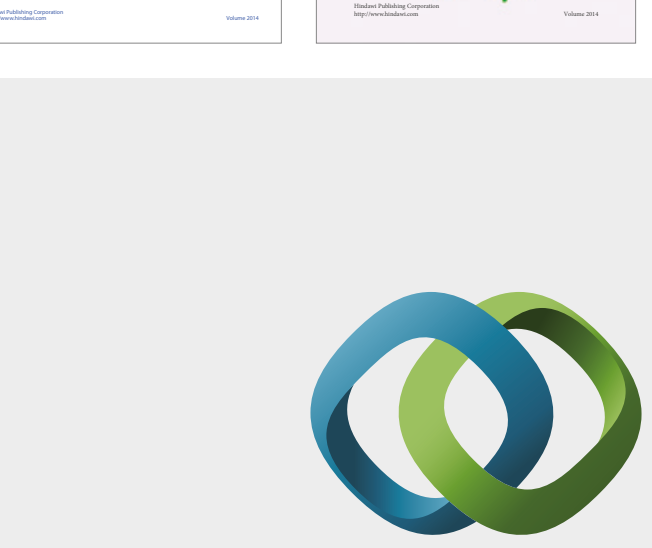

\section{Hindawi}

Submit your manuscripts at

https://www.hindawi.com
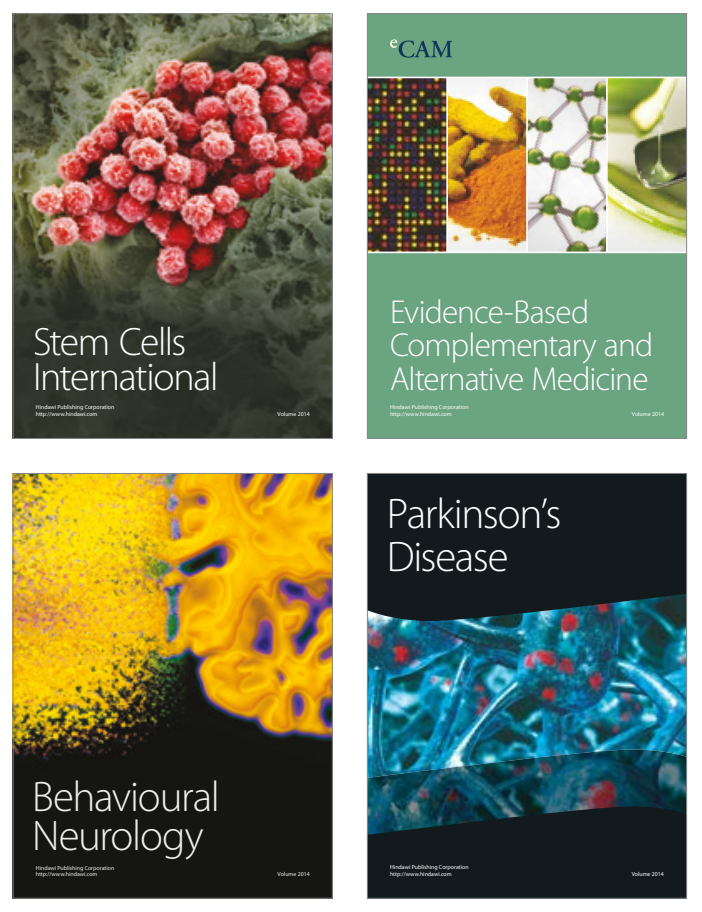
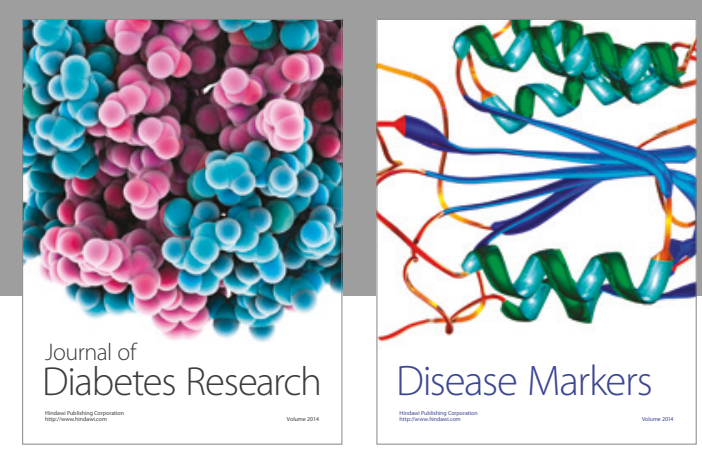

Disease Markers
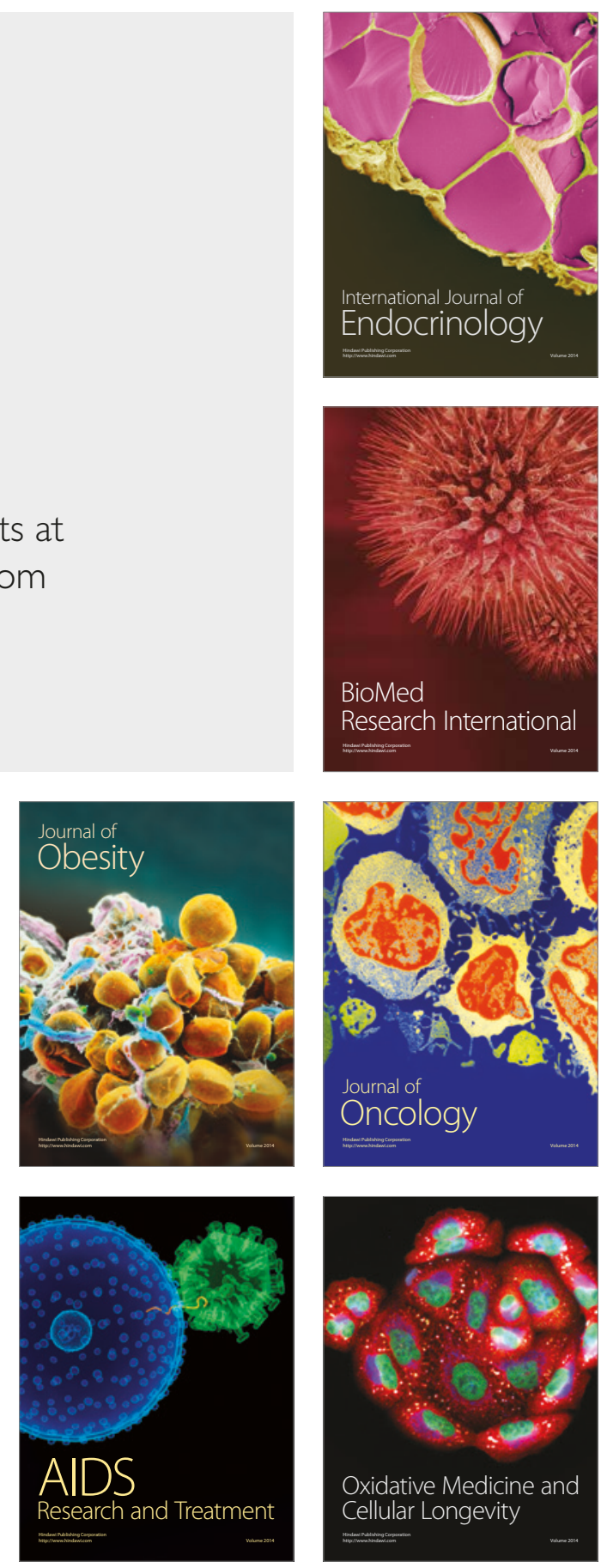